\title{
Hexabromocyclododecane and hexachlorocyclohexane: how \\ lessons learnt have led to improved regulation.
}

\author{
Cyril O. Onogbosele and Mark D. Scrimshaw*
}

Institute for the Environment, Brunel University, Uxbridge, Middlesex, UB8 3PH, UK

* Corresponding Author

e-mail mark.scrimshaw@brunel.ac.uk

Telephone +44 (0)1895 267299

Running header: Learning lessons from hexachlorocyclohexane

\begin{abstract}
The use of chemicals by society has many benefits but contamination of the environment is an unintended consequence. One example is the organochlorine compound hexachlorocyclohexane. During the 1980s, when hexachlorocyclohexane was banned in many countries, the brominated flame retardant, hexabromocyclododecane, found increasing use. The persistent, bioaccumulative and toxic characteristics of hexabromocyclododecane are, 30 years later, likely to warrant global action on production and use under the Stockholm Convention on POPs. Historical lessons have taught us that we need to control the use of chemicals and programmes are in place worldwide in an attempt to do so.
\end{abstract}




\subsection{Introduction}

Over the years, the growth of the chemical industry and the manufacture and use of a number of chemical substances have resulted in global contamination of the environment with some chemical substances. In particular, those classified as persistent organic pollutants (POPs) have attracted attention due to a growing body of scientific evidence of their PBT properties and the potential for long-range environmental transport (UNEP, 2009). Among POPs are the synthetic organohalogens, hexachlorocyclohexane $(\mathrm{HCH})$ and hexabromocyclododecane (HBCD). The manufacture and use of $\mathrm{HCH}$ began much earlier than that of HBCD (Breivik et al., 1999; Alaee et al., 2003). For several years, the environmental fate and toxicological effects of $\mathrm{HCH}$ were extensively studied and known before the manufacture and use of HBCD (ATSDR, 2005; EC, 2008).

With the molecular formula $\mathrm{C}_{6} \mathrm{H}_{6} \mathrm{Cl}_{6}, \mathrm{HCH}$ is an organochlorine first synthesized in 1825 by photochlorination of benzene, and was then known as benzene hexachloride (BHC) (CEC, 2006). Technical $\mathrm{HCH}$ is a mixture of five isomers: $\alpha$ (alpha)-HCH (55-80\%), $\beta$ (beta)-HCH (514\%), $\gamma$ (gamma)-HCH (8-15\%), $\delta$ (delta)-HCH (2-16\%) and $\varepsilon$ (epsilon)-HCH (3-5\%) (Vijgen et al., 2011). The proportion of the different isomers in technical products varied due to differences in production processes. The most environmentally significant isomers are the $\alpha$, $\beta$ and $\gamma$ isomers. The insecticidal property of $\mathrm{HCH}$ virtually exhibited by the $\gamma$ isomer was discovered in 1942. The $\mathrm{Y}-\mathrm{HCH}$ was then named lindane after Van Linden, the discoverer of the $\alpha$ and $\gamma$ isomers (CEC, 2006). With the exception of $\gamma-\mathrm{HCH}$, the other isomers of $\mathrm{HCH}$ became residues of the production process. Technical $\mathrm{HCH}$ was used in the control of insect pests until the late 1970 s when it was replaced by lindane ( $\geq 99 \%$ - $\mathrm{HCH}$ ) (Breivik et al., 1999). The production of 1 tonne of lindane generated approximately 6-10 tonnes of $\alpha$ - and 
$\beta-\mathrm{HCH}$ and as a result of the waste isomers generated, the production and regulation of lindane was a global problem for many years (IHPA, 2006).

Lindane and technical $\mathrm{HCH}$ have been used in the treatment of fruits, food crops, ornamental plants, seeds, forestry products, soil, livestock and pets to eradicate pests such as insects, ticks and mites (Li, 1999). The insecticide has also been used as a pharmaceutical formulation in shampoo, lotions or creams for treatment of head lice and scabies (mite infection) in humans (WHO, 1991). It is estimated that from 1950 to 2000 , about 600,000 tonnes of lindane was used globally; on an annual basis this was about 12,000 tonnes per annum over a period of 50 years. The estimated use in agriculture in Europe, Asia, Africa and Oceania were $287,160,73,200,63,570,28,540$ and 1,030 tonnes, respectively (IHPA, 2006). Breivik et al. (1999) reported that 382,000 tonnes of technical $\mathrm{HCH}$ and 81,000 tonnes of lindane were used in Europe from 1970 to 1996. In addition, they observed an estimated cumulative usage of 259,000 tonnes of $\alpha-\mathrm{HCH}, 135,000$ tonnes of $\mathrm{\gamma}-\mathrm{HCH}$ and 20,000 tonnes of $\beta-\mathrm{HCH}$.

Release of $\mathrm{HCH}$ to the environment involves several pathways: emissions from manufacturing sites; volatilization to the atmosphere during application in agriculture; atmospheric deposition; leaching in soil and release from stockpiles of disposed residual $\mathrm{HCH}$ isomers (UNEP, 2006). Exposure of biota (including humans) to $\mathrm{HCH}$ is mainly through intake of contaminated food and water. In addition, human exposure to lindane may be by direct contact during its application for pharmaceutical and agricultural purposes (CEC, 2006; UNEP, 2006). Because of the adverse effects of lindane on the environment and human health, by 2006, the use of lindane had been banned in 52 countries, and restricted in 33 countries (CEC, 2006). The proposal to list lindane and $\alpha-$ and $\beta-\mathrm{HCH}$ on Annex $\mathrm{A}$ 
(elimination) of Stockholm Convention on POPs was made by Mexico in 2005 and 2006, respectively (Vijgen et al., 2011). In 2009, they were finally listed on Annex A of Stockholm Convention on POPs. This implied a global ban on the production and use of lindane, and $\alpha-$ and $\beta-\mathrm{HCH}$. However, a specific exemption (5 years limit effective 2009) allows the use of lindane as a human health pharmaceutical for the control of head lice and scabies as second line treatment (UNEP, 2009).

A halogenated cyclic alkane, similar in structure to $\mathrm{HCH}$ (Fig. 1), HBCD has a molecular formula of $\mathrm{C}_{12} \mathrm{H}_{18} \mathrm{Br}_{6}$, and is an additive brominated flame retardant (BFR) produced by bromination of 1,5,9-cyclododecatriene (Heeb et al., 2005). As a flame retardant, it is incorporated into a wide range of consumer products to resist ignition of combustion and prevent or reduce flammability, particularly in materials that are susceptible to combustion (BSEF, 2009). Law et al. (2005) described 16 possible stereoisomers of HBCD comprising 6 pairs of enantiomers and 4 mesoforms. However, technical HBCD is a mixture of 3 diastereomers: $\alpha-\mathrm{HBCD}$ (10-13\%), $\beta-\mathrm{HBCD}(1-12 \%)$ and $\gamma$-HBCD (75-89\%) (Covaci et al., 2006). Like $\mathrm{HCH}$, the complex stereochemistry of $\mathrm{HBCD}$ and the differential environmental behaviour and fate of its isomers have made chemical analysis and regulation of $\mathrm{HBCD}$ difficult (Law et al., 2005; Janak et al., 2005). The production of HBCD for use as a BFR in polystyrene materials commenced in the 1980 s, though the chemical had been available on the market since the 1960s (EC, 2008). $\mathrm{HCH}$ had been in use for at least, 2 decades before the global introduction of $H B C D$. HBCD is mainly used in expanded polystyrene (EPS), extruded polystyrene (XPS) and backcoating of textiles for upholstered furniture, upholstery seating in transportation vehicles, draperies, wall coverings, mattress ticking and interior textiles such as car cushions and roller blinds (Swedish Chemicals Agency, 2008). 
Polystyrenes are principally used for thermal insulation boards in construction and building industries (Darnerud, 2003). In Europe in particular, HBCD is also used in high impact polystyrene (HIPS) for electrical and electronic equipment such as audio-visual equipment cabinets, wire and cable distribution boxes and refrigerator lining (ECHA, 2009). Deng et al. (2009) observed that the estimated total market demand for HBCD in 2001 globally was over 16,700 tonnes, with 2,800 tonnes from USA, 9,500 tonnes from Europe, 3,900 tonnes from Asia and 500 tonnes from the rest of the world. In 2002 and 2003, the global demands were 21,447 and 21,951 tonnes, respectively (UNEP, 2010b). The increasing global demand for HBCD has resulted in an annual production of almost twice that historically reached for $\mathrm{HCH}$.<smiles>ClC1C(Cl)C(Cl)C(Cl)C(Cl)C1Cl</smiles>

Hexachlorocyclohexane $(\mathrm{HCH})$<smiles>BrC1CCC(Br)C(Br)CCC(Br)C(Br)CCC1Br</smiles>

Hexabromocyclododecane (HBCD)

Figure 1. The structures of the two halogenated cyclic alkanes, $\mathrm{HCH}$ and $\mathrm{HBCD}$

Release of HBCD to the environment may arise from emissions and discharge of HBCD from manufacturing sites (Covaci et al., 2006), and the use and disposal of its products (Wu et al., 2011). HBCD is an additive flame retardant; it is not chemically bound to the material it 
protects unlike reactive flame retardants. Therefore, it is predisposed to high leaching and release to the environment from its products in use or after disposal (USEPA, 2010). Evidence of the distribution of HBCD in environmental media such as air, soil, sediments, surface water and sewage sludge, and biota (including humans) have been reported (ECHA, 2008; Environment Canada, 2011). Because of its volatility, atmospheric transport is also an important pathway for transport of HBCD within the environment (de Wit et al., 2010). In the European Union, due to the PBT properties of HBCD, HBCD has been identified as a substance of very high concern (SVHC) within the Registration, Evaluation, Authorization and Restriction of Chemicals (REACH) framework (ECHA, 2008). In the USA, HBCD is also considered to be of high concern based on its PBT properties, high toxicity to aquatic organisms and occurrence in remote regions of the world (UNEP, 2010a).

HBCD is among new POPs being considered for global elimination. It was nominated by Norway in 2008 for listing in the annexes of Stockholm Convention on POPs. It has met criteria for inclusion in Annex D of the Convention based on the screening criteria of PBT properties and the potential for long-range environmental transport, and completed the Annex E assessment (UNEP, 2010a). The Persistent Organic Pollutants Review Committee (POPRC), a subsidiary body of Stockholm Convention mandated to assess a given proposal by a Party for listing of a chemical as a POP in Annex(es) A, B (restriction) and/or C (unintentional production), at its sixth meeting held from 11-15 October 2010 in Geneva, Switzerland, considered and adopted the risk profile of HBCD. It was concluded that HBCD should proceed to Annex F (management evaluation). At its seventh meeting held from 10 14 October 2011 in Geneva, the Committee considered a draft risk management plan for possible control measures and socio-economic considerations and recommended that HBCD 
should be listed in Annex A as a control measure. However, the recommendation is yet to be adopted by the Convention (UNEP, 2011).

This paper will comparatively review the PBT properties and the potential for long-range environmental transport of $\mathrm{HCH}$ and $\mathrm{HBCD}$, and evaluate where the consequences of using $\mathrm{HBCD}$ could have been foreseen as a result the early warnings from $\mathrm{HCH}$.

\subsection{Persistence}

Characteristically, $\mathrm{HCH}$ and $\mathrm{HBCD}$ are persistent and resistant to degradation. Though degradation by microorganisms may result in the slow removal of $\mathrm{HCH}$ from water, photolysis and hydrolysis are not considered to be significant pathways for degradation of $\mathrm{HCH}$ isomers (CEC, 2006; Addison et al., 2009; Hu et al., 2010). Once released to the environment, $\mathrm{HCH}$ partitions into the air, water, sediments and soil, and accumulates in biota. Technical $\mathrm{HCH}$ is no longer used as an insecticide in most parts of the world, but its isomers are still reported to occur in surface waters, sediments, soil and biota in countries where it has long been banned because of its persistence in the environment (Zhao et al., 2009; Hu et al., 2010; Vijgen et al., 2011). Among banned organochlorines, Brun et al. (2008) reported $\alpha$ - and $\gamma-\mathrm{HCH}$ among the most frequently detected chemical substances in wetprecipitation across Atlantic Canada.

Chen et al. (1984) reported half-lives of 91 hours (3.79 days), 152 hours (6.33 days) and 104 hours (4.33 days) for $\alpha-\mathrm{HCH}, \beta-\mathrm{HCH}$ and $\mathrm{\gamma}-\mathrm{HCH}$, respectively, in the air. Hydrolytic half-lives of 0.8 year $\left(292\right.$ days) $\left(\mathrm{pH} 8.0,20^{\circ} \mathrm{C}\right)$ and 26 years $\left(\mathrm{pH} 7.8,5^{\circ} \mathrm{C}\right)$ were estimated for $\alpha-\mathrm{HCH}$ by Ngabe et al. (1993). In addition, Harner et al. (1999) estimated a half-life of 63 years for $\alpha-$ 
$\mathrm{HCH}$ in the Arctic Ocean. In natural freshwaters such as rivers and lakes, the estimated halflives for $\mathrm{\gamma}-\mathrm{HCH} /$ lindane range from 3 to 300 days (Mackay et al., 1997). In seawater (pH 8.0, $20^{\circ} \mathrm{C}$ ), a half-life of 1.1 years is estimated while 110 years is estimated in the Arctic Ocean (pH 8.0, $\left.0^{\circ} \mathrm{C}\right)$ for lindane (UNEP, 2006). In soils, half-lives of 55 days (Singh et al., 1991) and 161 days (Doelman et al., 1990) for $\alpha-\mathrm{HCH}, 100$ and 184 days for $\beta-\mathrm{HCH}$ (Singh et al., 1991), and 88 to 1146 days (aerobic conditions) and 12 to 174 days (anaerobic conditions) for $\gamma$ $\mathrm{HCH}$ (Slooff and Matthijsen, 1988; IPCS, 1991), have been reported. Information on degradation half-lives of $\mathrm{HCH}$ in sediments is limited. However, in aquatic sediments, halflives of 90 days (WWFC, 1999), and $0.9,12.6$ and 1.26 years for $\alpha-, \beta$ - and $\nu-H C H$, respectively, in the Arctic (Helm et al., 2002) have been estimated. In environmental media, $\beta-\mathrm{HCH}$ does not undergo degradation easily. Compared to other $\mathrm{HCH}$ isomers, it is detected most commonly in environmental media due to its lower water solubility (higher $\mathrm{k}_{\text {ow }}$ ) and greater chemical stability (Bhatt et al., 2009). HCH persists in biota. Data on the occurrence of $\mathrm{HCH}$ in biota are usually in the form of concentrations rather than biological half-lives, although in humans, an estimated half-life of 7 to 10 years for $\beta-\mathrm{HCH}$, which is the predominant isomer in mammals, has been reported (Zou and Matsumura, 2003).

$\mathrm{HBCD}$ also has the propensity for persistence. Like $\mathrm{HCH}$, half-lives in air and water greater than the regulatory thresholds of $>2$ and $>60$ days (UNEP, 2001), respectively, have been reported (Table 1). However, there appears to be a lack of experimental data on the degradation half-life of HBCD in both freshwater and marine water. The range of values (60130 days) stated in Table 1 for HBCD are rather estimates derived from models. In studies on the biodegradation of HBCD in aquatic sediments, half-lives of 210, 130 and 190 days (aerobic) and 210, 80 and 125 days (anaerobic) for $\alpha-, \beta$ - and $\psi-H B C D$, respectively, have 
been reported. However, using temperature of $12^{\circ} \mathrm{C}$ as benchmark, the half-life of $\mathrm{HBCD}$ in sediments is estimated to be $125-191$ days (EC, 2008). Compared to $\beta$ - and $\gamma-H B C D, \alpha-H B C D$ is resistant to reductive dehalogenation under anaerobic condition in sediments (EC, 2008). Data on degradation half-lives of HBCD in soils are limited. Davis et al. (2005) determined half-lives of 63 and 6.9 days in aerobic and anaerobic soils, respectively, for HBCD. However, in the study, degradation products were not reported, and only the fate of $\gamma-H B C D$ was determined. On the basis of empirical data primarily, the half-life of HBCD in soil is $\geq 182$ days (Environment Canada, 2011).

Table 1. A comparison of the persistence of $\mathrm{HCH}$ and $\mathrm{HBCD}$ in environmental media.

\begin{tabular}{|c|c|c|c|}
\hline Criterion & $\begin{array}{l}\text { Regulatory } \\
\text { threshold } \\
(\text { UNEP, 2001) }\end{array}$ & $\mathrm{HCH}$ & HBCD \\
\hline Half-life in air & $>2$ days & $\begin{array}{l}3.7 \text { to } 6.33 \text { (Chen et } \\
\text { al., 1984) }\end{array}$ & $\begin{array}{l}0.4 \text { to } 5.2 \text { (Marvin et al., } \\
\text { 2011) }\end{array}$ \\
\hline Half-life in water & $>60$ days & $\begin{array}{l}3 \text { to } 300 \text { days } \\
\text { (Mackay et al., 1997) }\end{array}$ & $\begin{array}{l}60 \text { to } 130 \text { days (Marvin et } \\
\text { al., 2011) }\end{array}$ \\
\hline $\begin{array}{l}\text { Half-life in aquatic } \\
\text { sediments }\end{array}$ & $>180$ days & $\begin{array}{l}90 \text { days (WWFC, } \\
1999) \\
0.9 \text { to } 12.6 \text { years } \\
\text { (Helm et al., 2002) }\end{array}$ & 125-191 days (EC, 2008) \\
\hline Half-life in soil & $>180$ days & $\begin{array}{l}<180-1146 \text { (IPCS, } \\
1991)\end{array}$ & $\begin{array}{l}6.9 \text { to } 63 \text { days (Davis et al., } \\
2005 \text { ) } \\
\geq 182 \text { days (Environment } \\
\text { Canada, 2011) }\end{array}$ \\
\hline $\begin{array}{l}\text { Half-life in biota } \\
\text { (days/years) }\end{array}$ & none & $\begin{array}{l}7 \text { to } 10 \text { years } \\
\text { (humans) (Zou and } \\
\text { Matsumura, 2003) }\end{array}$ & $\begin{array}{l}23 \text { to } 219 \text { days (humans) } \\
\text { (Schecter et al., 2012) } \\
1 \text { to } 17 \text { days (mice) } \\
\text { (Schecter et al., 2012) } \\
53 \text { to } 136 \text { days (fish) (Janak } \\
\text { et al., 2005) }\end{array}$ \\
\hline
\end{tabular}


When released to the environment, HBCD isomers will adsorb onto solid particles of sediments and soil (Janak et al., 2005). Though there is a predominance (>90\%) of $y$-HCBD in the environment compared to $\alpha$ - and $\beta-H B C D, \alpha-H B C D$ often has the highest prevalence in biota, followed by $\beta-$ HBCD (Birnbaum and Staskal, 2004). This has been attributed to bioisomerization of the diastereomers and differences in the metabolizing capacity of organisms, particularly fish (Law et al., 2004; Janak et al., 2005). Half-lives of 136 and 53 days for $\alpha$ - and $\beta-H B C D$, respectively, in Oncorhynchus mykiss (rainbow trout) have been reported (Janak et al., 2005).

The abundance of $\mathrm{HBCD}$ in environmental media in remote locations such as the Arctic without demonstrable existing sources of exposure, and its trophic transfer in food webs provide evidence of persistence of $H B C D$. Concentrations of $H B C D$ measured in dated sediment core samples indicate widespread occurrence and also provide evidence of the persistence of HBCD in the environment (UNEP, 2007a). Generally, $\mathrm{HCH}$ is more persistent in environmental media than $\mathrm{HBCD}$ (Table 1), however isomers of both $\mathrm{HCH}$ and, $\mathrm{HBCD}$ exhibit differences in their persistence in environmental media.

\subsection{Bioaccumulation}

Octanol-water partition coefficient (Kow) and bioconcentration factor (BCF) are used to assess the potential for a chemical to bioaccumulate. Log $K_{\text {ow }}$ values of $3.8,3.78$ and 3.72 for $\alpha-, \beta$ - and $\gamma-\mathrm{HCH}$, respectively (ATSDR, 2005), indicate a potential for bioaccumulation. A wide range of $\mathrm{BCFs}$ for $\mathrm{HCH}$ have been reported in several studies. Oliver and Niimi (1985) reported BCF of $1100-2800$ in fish. In invertebrates, BCFs ranging from $60-2,750$ have 
been estimated (UNEP, 2007b). Due to its lipophilicity, $\mathrm{HCH}$ accumulates in food chains. It has been reported to accumulate rapidly in invertebrates, fish, birds and mammals (CEC, 2006). In biota, particularly mammals, the variations observed in the isomeric composition of $\mathrm{HCH}$ may be due to differences in sources and time of exposure, isomeric uptake, metabolism and adiposity of species (Willett et al., 1998). Generally, $\beta-\mathrm{HCH}$ being the most persistent and bioaccumulative isomer, may exhibit highest prevalence among $\mathrm{HCH}$ isomers detected in mammalian tissues (Solomon and Weiss, 2002; Liu and Macdonald, 2005). This is attributable to the greater resistance to metabolism and the much longer half-life of $\beta$ $\mathrm{HCH}$ than other $\mathrm{HCH}$ isomers in adipose tissues of mammals (Liu and Macdonald, 2005). Zou and Matsumura (2003) reported the accumulation of $\beta-\mathrm{HCH}$ in the adipose and breast tissues of humans.

$\mathrm{HBCD}$ also has the potential for bioaccumulation like $\mathrm{HCH}$. However, the log $\mathrm{K}_{\mathrm{ow}}$ values of $H B C D$ are higher than those of $H C H$. For technical $H B C D, \alpha-H B C D, \beta-H B C D$ and $\gamma-H B C D$, the estimated log $K_{\text {ow }}$ values are 5.62, 5.07, 5.12 and 5.47, respectively (ECHA, 2008). HBCD has low water solubility of $66 \mu \mathrm{g} / \mathrm{l}$ (Swedish Chemicals Agency, 2008). Because of its hydrophobicity and lipophilicity, it exhibits partitioning into adipose tissues in biota, followed by accumulation, characteristic of many POPs (de Wit. 2002; Law et al., 2003). The accumulation of HBCD in different organisms such as invertebrates, fish, birds and mammals (including humans), and its biomagnification in food chains have been reported (Tomy et al., 2004; Law et al., 2006; Covaci et al ., 2006). BCFs of 18,100 in Pimephales promelas (fathead minnows) (Veith et al., 1979) and 19,200 in O. mykiss (Drottar et al., 2001) have been measured. Stereoisomer-specific bioaccumulation has been observed in HBCD. Like HCH, HBCD seems to undergo stereoselective processes such as biotransformation and 
bioisomerization in the environment, resulting in relative enrichment of different stereoisomers (Law et al., 2005; Janak et al., 2005; Heeb et al., 2008).This has been observed in the preferential accumulation of $\alpha-H B C D$ in relation to the much dominant $\gamma$ HBCD in the technical HBCD mixture (Janak et al., 2005). Differences in the water solubility of HBCD stereoisomers (48.8, 14.7 and $2.1 \mu \mathrm{g} / \mathrm{I}$ for $\alpha-, \beta$ - and $\mathrm{H}^{\mathrm{HBCD}}$, respectively) may also be responsible for differences in the metabolism and bioaccumulation of the stereoisomers (Hunziker et al., 2004). The regulatory criteria for bioaccumulation assessment based on $\mathrm{K}_{\mathrm{ow}}$ and BCF include United Nations Environment Programme (UNEP) (Stockholm Convention on POPs), $\log \mathrm{K}_{\mathrm{ow}} \geq 5$ and $\mathrm{BCF} \geq 5000$; European Union (REACH), BCFs $\geq 2000$ (bioaccumulative) and $\geq 5000$ (very bioaccumulative); United States (Toxic Substances Control Act), BCFs of $1000-5000$ (bioaccumulative) and $\geq 5000$ (very bioaccumulative), and Environment Canada (Canadian Environment Protection Act), $\log \mathrm{K}_{\mathrm{ow}} \geq 5$ and $\mathrm{BCF} \geq 5000$ (Arnot and Gobas, 2006). On the basis of these criteria, $\mathrm{HBCD}$ is much more bioaccumulative than $\mathrm{HCH}$.

\subsection{Toxicity}

Reported adverse effects of $\mathrm{HCH}$ (Table 2) in laboratory animals and humans include carcinogenicity, genotoxicity, neurotoxicity, developmental toxicity, endocrine disruption, reproductive disorders, haematological alterations and immunosuppression (ATSDR, 2005; UNEP, 2006). Mathur et al. (2002) reported $\beta-\mathrm{HCH}$ levels to be significantly higher in breast cancer patients, $31-50$ years of age in relation to non-cancer patients. $\beta-\mathrm{HCH}$ is a risk factor for the progression of breast cancer cells to advanced state of malignancy (Zou and Matsumura, 2003). Studies by Khan et al. (2010) indicated a positive significant association between sperm count and the level of $\alpha-$ and $\beta-\mathrm{HCH}$ in infertile human males as a result of $Y$ 
chromosome microdeletions by the $\mathrm{HCH}$ isomers. $\mathrm{HCH}$ is mutagenic, and can cause spermatogenic failure in humans. Neurological effects such as seizures, convulsion and coma in humans, and immunosuppression and suppressed antibody responses in laboratory animals arising from exposure to lindane have been observed (WHO/Europe, 2003). Prenatal exposure to $\beta-\mathrm{HCH}$ has been associated with alteration in thyroid hormone levels and possible adverse brain development in humans (Alvarez-Pedrerol et al., 2008). Studies on rats and rabbits have indicated reproductive disorders such as reduced ovulation, reduction in the number of testicular spermatids and epididymal sperms, degeneration of seminiferous tubules and disruption of spermatogenesis as a result of exposure to lindane. Haematological changes such as leukocytosis, granulocytosis, eosinophilia, thrombocytopenia and leukopenia have also been observed in humans following chronic exposure to lindane (UNEP, 2006). Acute exposure to lindane in humans may cause adverse effects ranging from skin irritation to dizziness, diarrhoea, vomiting, headache nausea convulsion and death (CEC, 2006).

The ecotoxicity of $\mathrm{HCH}$ has been extensively studied. Lindane is toxic to aquatic organisms. Schafer et al. (1994) reported lindane's inhibiton of growth in the freshwater algae, Chlamydomonas reinhardi and Scenedesmus subspicatus at $72 \mathrm{~h} \mathrm{EC} 50$ of $4.0 \mathrm{mg} / \mathrm{l}$ and $72 \mathrm{~h}$ $\mathrm{EC}_{50}$ of $3.2 \mathrm{mg} / \mathrm{l}$, respectively. The $\mathrm{LC}_{50}$ (median lethal concentration) for aquatic invertebrates and fish ranges from 10-520 $\mu \mathrm{g} / \mathrm{l}$ and 1.7-131 $\mu \mathrm{g} / \mathrm{l}$, respectively (UNEP, 2006). Studies on the chronic toxicity of lindane showed reduction in the growth of freshwater fish larvae at a NOAEC (no observed adverse effect concentration) of $2.9 \mu \mathrm{g} / \mathrm{l}$, and decline in reproduction in aquatic invertebrates at NOAEC of $54 \mu \mathrm{g} / \mathrm{I}$ (UNEP, 2006). In aquatic birds 
and mammals generally, chronic exposure to lindane has resulted in reduced rate of growth and survival, decrease in body weight and egg production and endocrine disruption as important endpoints (CEC, 2006). In the terrestrial environment, Pereira et al. (2010) reported on the phytotoxicity of $\mathrm{HCH}$ in relation to the germination and growth responses of different plant species.

Unlike $\mathrm{HCH}$, information on the relative toxicity of the different isomers of $\mathrm{HBCD}$ in humans and wildlife is virtually lacking. However, extrapolations of toxicological tests on technical $\mathrm{HBCD}$ mixture in mammals strongly indicate that $\mathrm{HBCD}$ has the potential to cause adverse effects in humans (Table 2). These include endocrine disruption, particularly of the thyroidhormone system (Ibhazehiebo et al., 2011); neurotoxicity (learning and memory defects) (Reistad et al., 2006; Eriksson et al., 2006); reproductive disorders such as inhibition of oogenesis (Darnerud, 2003), and adverse effect on liver weight and activity (Germer et al., 2006). The possible role of HBCD in carcinogenicity is not known. The limited data indicate that with the exception of endocrine disruption in mammalian cell cultures, where effects occurred at concentrations of $\mathrm{mg} / \mathrm{l}$ rather than $\mu \mathrm{g} / \mathrm{l}$, risks posed by HBCD to mammals are not greater than those of $\mathrm{HCH}$.

Ecotoxicity studies (Table 2 and Figure 2) have shown that HBCD like $\mathrm{HCH}$ can potentially produce adverse effects in aquatic organisms, particularly algae, invertebrates, fish, birds and mammals, and terrestrial organisms at environmentally relevant concentrations (Darnerud, 2003; Birbaum and Staskal, 2004). Generally, laboratory studies on the toxicity of HBCD to aquatic organisms indicate endpoints such as inhibition of survival, growth, development and reproduction, endocrine disruption, histopathological changes, oxidative 
Table 2. Comparative toxicity of $\mathrm{HCH}$ and $\mathrm{HBCD}$. A comparison of values for ecotoxicity is shown in Figure 2.

\begin{tabular}{|c|c|c|c|}
\hline \multicolumn{2}{|c|}{ Toxicity } & \multirow[t]{2}{*}{$\mathrm{HCH}$} & \multirow[b]{2}{*}{ No data } \\
\hline $\begin{array}{l}\text { Mammalian } \\
\text { toxicity }\end{array}$ & Carcinogenicity & & \\
\hline & Genotoxicity & $\begin{array}{l}\alpha-\mathrm{HCH} 130 \mu \mathrm{g} / \mathrm{l} ; \beta \mathrm{HCH} 300 \\
\mu \mathrm{g} / \mathrm{l} \text { in vitro (Khan et al., 2010) }\end{array}$ & No data \\
\hline & Neurotoxicity & $\begin{array}{l}\alpha-\mathrm{HCH} \text { at } 23.4 \mathrm{mg} / \mathrm{kg} / \mathrm{day} \text { in } \\
\text { rats (WHO Europe, 2003) }\end{array}$ & $\begin{array}{l}13.5 \mathrm{mg} / \mathrm{kg} / \mathrm{day} \text { in mice } \\
\text { (Eriksson et al., 2006) }\end{array}$ \\
\hline & $\begin{array}{l}\text { Reproductive } \\
\text { toxicity }\end{array}$ & $\begin{array}{l}\mathrm{Y}-\mathrm{HCH} 6 \mathrm{mg} / \mathrm{kg} / \mathrm{day} \text { in male } \\
\text { rats (ATSDR, 2005) }\end{array}$ & $\begin{array}{l}2,500 \mathrm{mg} / \mathrm{kg} / \mathrm{day} \text { in rats } \\
\text { (Darnerud, 2003) }\end{array}$ \\
\hline & $\begin{array}{l}\text { Developmental } \\
\text { toxicity }\end{array}$ & $\begin{array}{l}\mathrm{Y}-\mathrm{HCH} 13.1 \mathrm{mg} / \mathrm{kg} / \mathrm{day} \text { in rats } \\
\text { (ATSDR, 2005) }\end{array}$ & $\begin{array}{l}\text { Has the potential (UNEP, } \\
2010 \mathrm{~b})\end{array}$ \\
\hline & Immunotoxicity & $\begin{array}{l}\mathrm{Y}-\mathrm{HCH} \text { 6- } 25 \mathrm{mg} / \mathrm{kg} / \mathrm{day} \text { in rats } \\
(\mathrm{UNEP}, 2006)\end{array}$ & No data \\
\hline & $\begin{array}{l}\text { Endocrine } \\
\text { disruption }\end{array}$ & $\begin{array}{l}\beta \text { - and } \gamma-\mathrm{HCH} \text { (UNEP, 2006; } \\
\text { Alvarez-Pedrerol et al., 2008) }\end{array}$ & $\begin{array}{l}\text { Has the potential (UNEP, } \\
\text { 2010b) }\end{array}$ \\
\hline & & $\begin{array}{l}\text { Technical } \mathrm{HCH} 3 \text { to } 11 \mathrm{mg} / \mathrm{l} \text { in } \\
\text { vitro (mammalian cells) } \\
\text { (Tiemann, 2008) }\end{array}$ & $\begin{array}{l}\alpha-H B C D \\
\text { (mammalian cells) } \\
\text { (lbhazehiebo et al., 2011) }\end{array}$ \\
\hline \multirow[t]{9}{*}{ Ecotoxicity } & Acute toxicity & $\begin{array}{l}\text { Highly toxic to freshwater fish } \\
\text { (UNEP, 2006) }\end{array}$ & $\begin{array}{l}\text { Toxic to freshwater fish } \\
\text { embryos (Deng et al., 2009) }\end{array}$ \\
\hline & & $\begin{array}{l}\text { Highly toxic to aquatic } \\
\text { invertebrates (UNEP, 2006) }\end{array}$ & $\begin{array}{l}\text { Toxic to aquatic invertebrates } \\
(\mathrm{ECHA}, 2008)\end{array}$ \\
\hline & & $\begin{array}{l}\text { Moderately toxic to birds and } \\
\text { mammals (CEC, 2006) }\end{array}$ & $\begin{array}{l}\text { No data on acute toxicity to } \\
\text { birds and mammals }\end{array}$ \\
\hline & & $\begin{array}{l}\text { Highly toxic to algae (IPCS, } \\
\text { 1992; Schafer et al.,1994) }\end{array}$ & $\begin{array}{l}\text { Highly toxic to algae } \\
\text { (Desjardins et al., 2005) }\end{array}$ \\
\hline & Chronic toxicity & Aquatic biota (UNEP, 2006) & Aquatic biota $(E C, 2008)$ \\
\hline & $\begin{array}{l}\text { Inhibition of } \\
\text { growth and } \\
\text { survival }\end{array}$ & $\begin{array}{l}\text { In daphnids and fish } \\
\text { (Ferrando et al., 1995; Gorge } \\
\text { and Nagel, 1990) }\end{array}$ & $\begin{array}{l}\text { In daphnids and fish (Drottar } \\
\text { and Kruegar, 1998; Drottar et } \\
\text { al., 2001) }\end{array}$ \\
\hline & $\begin{array}{l}\text { Inhibition of } \\
\text { reproduction }\end{array}$ & $\begin{array}{l}\text { In aquatic invertebrates, birds } \\
\text { and mammals (UNEP, 2006) }\end{array}$ & $\begin{array}{l}\text { In daphnids, fish, birds, } \\
\text { mammals and earthworm } \\
\text { (UNEP, 2010b) }\end{array}$ \\
\hline & $\begin{array}{l}\text { Terrestrial } \\
\text { phytotoxicity }\end{array}$ & $\begin{array}{l}\text { Technical HCH } 1,250 \mathrm{mg} / \mathrm{kg} \text { in } \\
\text { soil (Pereira et al., 2010) }\end{array}$ & No (UNEP, 2010b) \\
\hline & $\begin{array}{l}\text { Endocrine } \\
\text { disruption }\end{array}$ & $\begin{array}{l}\text { Technical HCH } 1 \text { to } 10 \mathrm{mg} / \mathrm{l} \text { in } \\
\text { fish (Singh and Canario, 2004) }\end{array}$ & $\begin{array}{l}\text { In fish exposed to } 5 \mu \mathrm{g} / \mathrm{l} \\
\text { (Palace et al., 2010) }\end{array}$ \\
\hline
\end{tabular}


stress and apoptosis and mortality (Legler, 2008; Deng et al., 2009; Environment Canada, 2011; UNEP, 2010b). HBCD is highly toxic to algae. $72 \mathrm{~h} \mathrm{EC}_{50}$ (effective concentration in $50 \%$ ) values based on decrease in population density in marine algae range from 9.3-12 $\mu \mathrm{g} / \mathrm{l}$ in Skeletonema costatum, and 50-370 $\mu \mathrm{g} / \mathrm{l}$ in Thalassiosira pseudonana (Walsh et al., 1987). In studies by Roberts and Swigert (1997), $72 \mathrm{~h} \mathrm{EC}_{50}>2.5 \mu \mathrm{g} / \mathrm{l}$ was observed in the freshwater alga, Pseudokirchneriella subcapitata (=Selenastrum capricornutum). In the cladoceran crustacean, Daphnia magna (water flea), a 21-day chronic exposure to HBCD indicated a NOEC (no observed effect concentration) of $3.1 \mu \mathrm{g} / \mathrm{l}$ and a LOEC (lowest observed effect concentration) of $5.6 \mu \mathrm{g} / \mathrm{l}$ based on significant reduction in growth (Drottar and Krueger, 1998). Thyroid hormone-dependent development effects in tadpoles of Xenopus laevis (Schriks et al., 2006) and significant adverse changes in the levels and patterns of circulating thyroid hormones in Salmo salar (Atlantic salmon) (Lower and Moore, 2007) and O. mykiss (Palace et al., 2010) exposed to HBCD have been observed. HBCD has also been reported to cause malformation and reduction of the survival of embryos of zebrafish, Danio rerio at 96h exposure to concentrations of 0.5 and $1.0 \mathrm{mg} / \mathrm{l}$ (Deng et al., 2009). In the earthworm, Eisenia fetida, NOEC for survival and reproduction estimated as 4190 and $128 \mathrm{mg} \mathrm{HBCD} / \mathrm{kg}$ dry soil, respectively, have been observed following 56 days exposure (UNEP, 2010b).HBCD has also been evaluated for phytotoxicity in the terrestrial ecosystem. At NOEC>5000 mg $\mathrm{HBCD} / \mathrm{kg}$ dry soil, there was no adverse effect on seedling emergence in Zea mays (corn), Cucumber sativa (cucumber), Lycopersicon esculentum (tomato) and Glycine max (soybean) (UNEP,2010b). Overall, the data on ecotoxicity for HBCD indicate a risk to the environment at lower concentrations (10 to 100 times less) than posed by $\mathrm{HCH}$, which is reflected in the proposed environmental quality standards (EQS) for these compounds (Figure 2). 


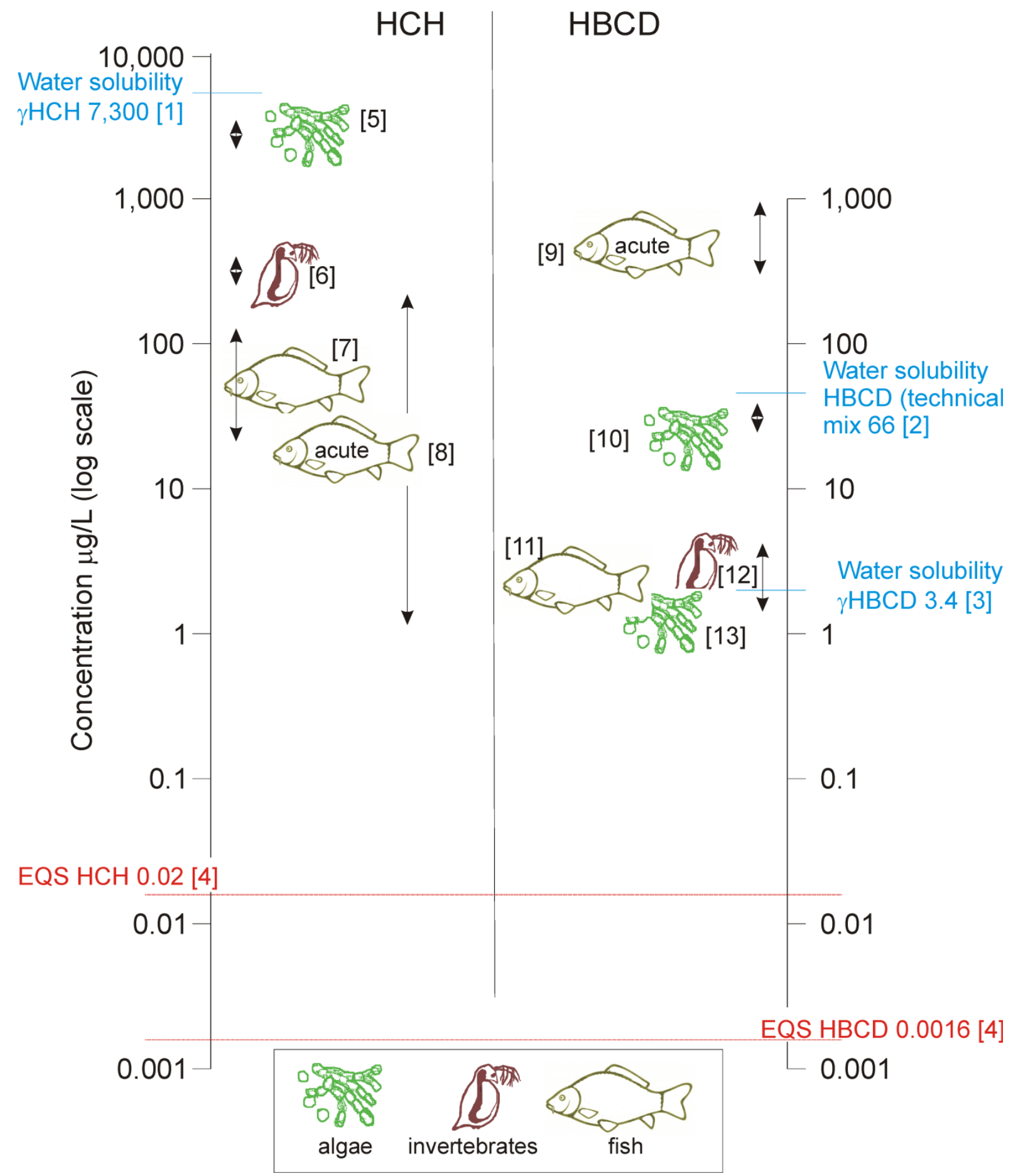

[1] Stenzel and Markley 1997; [2] HSDB, 2009; [3] UNEP, 2010b; [4] EC, 2012; [5] Schafer et al., 1994; [6] Ferrando et al., 1995; [7] George and Nagel, 1990; [8] UNEP, 2006; [9] Deng et al., 2009; [10] Desjardins et al., 2005; [11] Drottar et al., 2001; [12] Drottar and Krueger 1998; [13] Roberts and Swigert, 1997.

Figure 2 Graphical representation of the toxicity of $\mathrm{HCH}$ and $\mathrm{HBCD}$ in relation to their reported solubility and proposed (annual average) EQS. 


\subsection{Long-range Environmental Transport}

There is evidence of long-range environmental transport of $\mathrm{HCH}$ dating several decades. Several studies have reported the transport of $\mathrm{HCH}$ over long distances in the environment by air and ocean currents (Shen et al., 2005; Li and Macdonald, 2005; Brun et al., 2008). It is estimated that $12-30 \%$ of lindane used in agriculture volatilizes and becomes air-borne for long-range transport (USEPA, 2006). In the atmosphere, $\mathrm{HCH}$ condenses and deposits on oceans and freshwaters, and tends to accumulate in colder climates, particularly the Arctic where it is trapped by low evaporation rates (CEC, 2006). Far from important pollution sources, the Arctic is a recipient of $\mathrm{HCH}$ emitted from other parts of the world. In the Arctic, $\mathrm{HCH}$ has been detected in environmental media such as air (Li and Bidleman, 2003a) and water (Li and Macdonald, 2005), and biota (Willett et al., 1998; Hoekstra et al., 2002).

$\mathrm{HBCD}$ has the potential for long-range environmental transport and trans-boundary threat like $\mathrm{HCH}$. Arnot et al. (2009) observed that HBCD portioning behaviour in the atmosphere is such that at higher temperatures $\left(15-35^{\circ} \mathrm{C}\right)$ there is gaseous deposition while at lower temperatures $\left(-35-5^{\circ} \mathrm{C}\right)$ its association with particles will enhance the rate of dry deposition. Studies have indicated the occurrence of HBCD in water and sediments and biota such as fish, birds and mammals in remote regions of the world (for example, the Arctic) considered to be far from point sources of emission as a result of atmospheric deposition (Law et al ., 2006; de Wit et al .,2010; Letcher et al.,2010). Pollution of the Arctic with POPs such as HCH and $\mathrm{HBCD}$ is of great concern because people living in the Arctic are at high health risks due to their consumption of wildlife such as fish, birds and mammals with considerable quantities of these chemicals (CEC, 2006; UNEP, 2010b). It is concerns about the impacts of chemicals that has led to action by regulatory bodies worldwide. 


\subsection{Lessons Learnt: Regulation and Control}

It is apparent that the use of, and subsequent release of these two chemicals to the environment, has resulted in widespread contamination and significant concerns about the consequences of exposure of wildlife and humans. Although they are different chemicals, the two halogenated chemicals which have been discussed in this work are examples of compounds which, because of their toxicity and similar physico-chemical characteristics. Experience of chemicals in the environment has led to an approach to prioritise them based on such characteristics, and for regulators to focus on their PBT properties and the amount of chemicals that are in use, because impact is related to the concentration of a chemical. Perhaps the real lesson that society has learnt from the experience of using these, and similar chemicals, is that their release to the environment was in retrospect unwanted and unwise, and that tighter controls are required to prevent this occurring in future.

Regulators are now using such properties and usage patterns to prioritise chemicals for which control measures on use, or approval for use, are based. In the United Sates, the USEPA HPV Challenge Programme (USEPA, 2007), aims to make available health and environmental effects data for "chemicals produced or imported in the United States in quantities of 1 million pounds or more per year". Within Europe the Registration, Evaluation, Authorisation and Restriction of Chemical substances (REACH) system (EC, 2006), came into force in 2007 and those who manufacture or import chemicals are obliged to register information about them in a central database. The REACH regulations also allow for identification of the most hazardous chemicals and for their substitution with alternatives. From a world wide perspective, it is also important that countries showing strong economic growth are also involved in controlling chemicals. As well as being a 
signatory to the Stockholm Convention, China has newly enacted regulation, described as "China REACH" (Lau et al, 2012), which is aimed at ensuring the relevant authorities are notified about new chemical substances so that risks they pose can be effectively managed. There is, therefore, evidence that regulatory bodies worldwide are taking action to manage the use of chemicals, and the benefits of sound chemical management are of international concern (UNEP, 2012).

\subsection{Conclusions}

It is important for society to take stock of, and learn from past experiences in order to better protect the environment and prevent or reduce adverse consequences. The PBT properties and the long-range environmental transport exhibited by both $\mathrm{HCH}$ and $\mathrm{HBCD}$ have been affirmed by international treaties including the Stockholm Convention on POPs. It is apparent that our understanding of the fate and behaviour of chemicals has led to a number of frameworks where information can be utilised in future to minimise the risks that using chemicals can pose. There are increasing regulatory controls at both national and regional levels and that highlighting the benefits of managing chemicals is being undertaken at an international level.

\section{Acknowledgement}

Cyril Onogbosele is grateful to the Tertiary Education Trust Fund (TET Fund), Abuja, Nigeria. 


\section{References}

Addison R.F., Muir D.C.G., Ikonomou M.G., Harword L. and Smith T.G. 2009. Hexachlorocyclohexanes $(\mathrm{HCH})$ in ringed seal (Phoca hispida) from Ulukhaktok (Holman), NT: Trends from 1978 to 2006. Sci. Total Environ. 407, 5139-5146.

Alaee M., Arias P., Sjodin A. and Bergman A. 2003. An overview of commercially used brominated flame retardants, their applications, their patterns in different countries/regions and possible modes of release. Environ. Int. 29, 683-689.

Alvarez-Pedrerol M., Ribas-Fito N., Torrent M., Carrizo D., Garcia-Esteban R., Grimalt J.O. and Sunyer J. 2008. Thyroid disruption at birth due to prenatal exposure to $\beta$ hexachlorocyclohexane. Environ. Int. 34(6), 737-740.

Arnot J., McCarty L., Armitage J., Toose-Reid L., Wania F. and Cousin I. 2009. An evaluation of hexabromocyclododecane (HBCD) for persistent organic pollutant (POP) properties and the potential for adverse effects in the environment. Submitted to European Brominated Flame Retardant Industry Panel, May 26, 2009.

Arnot J.A. and Gobas F.A.P.C. 2006. A review of bioconcentration factor (BCF) and bioaccumulation factor (BAF) assessments for organic chemicals in aquatic organisms. Environ.Rev. 14, 257-297.

ATSDR. 2005. Toxicological profile for alpha-, beta-, gamma-, delta-hexachlorocyclohexane. U.S. Department of Health and Human Services, Public Health Service. Agency for Toxic Substances and Disease Registry, August 2005.

Bhatt P., Kumar M.S. and Chakrabarti T. 2009. Fate and degradation of POPhexachlorocyclohexane. Crit. Rev. Environ. Sci. Technol. 39, 655-695.

Birnbaum L.S. and Staskal D.F. 2004. Brominated flame retardants: cause for concern? Environ. Health Perspect. 112(1), 9-17.

Breivik K., Pacyna J.M. and Munch J. 1999. Use of $\alpha$-, $\beta$ - and $\gamma$-hexachlorocyclohexane in Europe, 1970-1996. Sci. Total Environ. 239, 151-163.

Brun G.L., MacDonald R.M., Verge J. and Aube J. 2008. Long-term atmospheric deposition of current-use and banned pesticides in Atlantic Canada: 1980-2000. Chemosphere 71, 314327.

BSEF, 2009. HBCD (hexabromocyclododecane). Fact Sheet, June 2009 edition. Bromine Science and Environmental Forum.

CEC, 2006. The North American Regional Action Plan (NARAP) on lindane and other hexachlorocyclohexane $(\mathrm{HCH})$ isomers. Commission for Environmental Cooperation, 30 November 2006. 
Chen Z.M., Zabik M.J. and Leavitt R.A. 1984. Comparative study of thin film photodegradative rates for 36 pesticide. In. Eng. Chem. Prod. Res. Dev. 23, 5-11.

Covaci A., Gerecke A.C., law R.J., Voorspoels S., Kohler M., Heeb N.V., Leslie H., Allchin C.R. and De Boer J. 2006. Hexabromocyclododecanes (HBCDs) in the environment and humans: a review. Environ. Sci. Technol. 40, 3679-3688.

Darnerud P.O. 2003. Toxic effects of brominated flame retardants in man and in wildlife. Environ. Int. 29, 841-853.

Davis J.W., Gonsior S., Marty G. and Ariano J. 2005. The transformation of hexabromocyclododecane in aerobic and anaerobic soils and aquatic sediments. Water Res. 39, 1075-1084.

de Wit C.A. 2002. An overview of brominated flame retardants in the environment. Chemosphere 46, 583-624.

de Wit C.A., Herzke D. and Vorkamp K. 2010. Brominated flame retardants in the Arctic environment - trends and new candidates. Sci. Total Environ. 408(15), 2885-2918.

Deng J., Yu L., Liu C., Yu K., Shi X., Yeung L.W.Y., Lam P.K.S., Wu R.S.S. and Zhou B. 2009. Hexabromocyclododecane-induced developmental toxicity and apoptosis in zebrafish embryos. Aquatic Toxicology 93, 29-36.

Desjardins D., MacGregor J.A. and Krueger H.O. 2005. Hexabromocyclododecane (HBCD): A 72-hour toxicity test with the marine diatom (Skeletonema costatum) using generator column saturated media. Chapter 2, Final report. Wildlife International Ltd., Easton, Maryland, USA. 19pp.

Doelman P., Haanstra L., Loonen H. and Vos A. 1990. Decomposition of alpha- and betahexachlorocyclohexane in soil under field conditions in a temperate climate. Soil Biol. Biochem. 22(5), 629-634.

Drottar K.R. and Krueger H.O. 1998. Hexabromocyclododecane (HBCD): A flow-through lifecycle toxicity test with the cladoceran (Daphnia magna). Final report. 439a-108. Wildlife International Ltd., Easton, Maryland, USA. p78.

Drottar K.R. and MacGregor J.A. and Krueger H.O. 2001. Hexabromocyclododecane (HBCD): An early life-stage toxicity test with rainbow trout (Oncorhynchus mykiss). Final Report. Wildlife International Ltd., Easton, Maryland, USA. pp1-102.

EC, 2006, "Registration, Evaluation, Authorisation and Restriction of Chemicals (REACH) Regulation. European Commission, Off. J. Eur. Commun. L395/17 (2006).

EC, 2008. Risk assessment: hexabromocyclododecane, CAS-NO: 25637-99-4, EINECS NO: 247-148-4, final report. European Commission, May 2008. 492pp. 
EC, 2012. Proposal for a Directive of the European Parliament and of the Council amending Directives 2000/60/EC and 2008/105/EC as regards priority substances in the field of water policy Brussels, 31.1.2012 COM(2011) 876 final 2011/0429 (COD)

ECHA, 2008. Member State Committee support document for identification of hexabromocyclododecane and all major diastereoisomers identified as a substance of very high concern. European Chemicals Agency, 8 October 2008.

ECHA, 2009. Data on the manufacture, import, export, uses and releases of HBCDD as well as information on potential alternatives to its use. European Chemicals Agency, 1 December 2009.

Environment Canada, 2011. Screening assessment report on hexabromocyclododecane. Chemical Abstracts Service Registry Number 3194-55-6. Environment Canada, Health Canada, November 2011.

Eriksson P., Fischer C., Wallin M., Jakobsson E. and Frederisson A. 2006. Impaired behaviour, learning and memory in adult mice neonatally exposed to hexabromocyclododecane (HBCDD). Environ. Toxicol. Pharmacol. 21, 317-322.

Ferrando M.D., Sancho E. and Andreumoliner E. 1995. Effects of lindane on Daphnia magna during chronic exposure. J. Environ. Sci. Health Part B 30(6), 815-825.

Germer S., Pierma A.H., van der Ven L., Kamyschnikow A., Fery Y., Schmitz H. and Schrenk D. 2006. Subacute effects of the brominated flame retardants hexabromocyclododecane and tetrabromobisphenol A on hepatic cytochrome P450 levels in rats. Toxicology 218, 229-236.

Gorge G. and Nagel R. 1990. Toxicity of lindane, atrazine and deltamethrin to early life stages of zebrafish (Brachydanio rerio). Ecotoxicol. Environ. Saf. 20, 246-255.

Harner T., Kylin H., Bidleman T.F. and Strachan W.M.J. 1999. Removal of alpha- and gammahexachlorocyclohexane and enantiomers of alpha-hexachlorocyclohexane in the Eastern Arctic Ocean. Environ. Sci. Technol. 33(88), 1157-1164.

Heeb N.V., Schweizer W.B., Kohler M. and Gerecke A.C. 2005. Structure elucidation of hexabromocyclododecanes - a class of compounds with a complex stereochemistry. Chemosphere 61, 65-73

Heeb N.V., Schweizer W.B., Mattrel P., Haag R., Gerecke A.C., Schmid P., Zennegg M. and Vonmont H. 2008. Regio- and stereoselective isomerisation of hexabromocyclododecanes (HBCDs): Kinetics and mechanism of $\gamma$ - to $\alpha-H B C D$ isomerisation. Chemosphere 73, 1201-1210 
Helm P.A., Diamond M.L., Semkin R., Strachan W.M.J., Teixeira C. and Gregor D. 2002. A mass balance model describing multiyear fate of organochlorine compounds in a high Arctic lake. Environ. Sci. Technol. 36(5), 996-1003.

Hoekstra P.F., O'Hara T.M., Pallant S.J., Solomon K.R. and Muir D.C.G. 2002. Bioaccumulation of organochlorine contaminants in bowhead whales (Balaena mysticetus) from Barrow Alaska. Arch. Environ. Contam. Toxicol. 42, 497-507.

HSDB, 2009. Hazardous Substances Data Bank. National Library of Medicine. http://toxnet.nlm.nih.gov/cgi-bin/sis/htmlgen?HSDB and search on "Lindane". Last accessed: $14 / 02 / 13$

Hu W., Wang T., Khim J.S., Luo W., Jiao W., Lu Y., Naile J.E., Chen C., Zhang X. and Giesy J.P. 2010. $\mathrm{HCH}$ and DDT in sediments from marine and adjacent riverine areas of North Bohai Sea, China. Arch. Environ. Contam. Toxicol. 59, 71-79.

Hunziker R.W., Gonsior S., MacGregor J.A., Desjardins D., Ariano J. and Friederich U. 2004. Fate and effect of hexabromocyclododecane in the environment. Organohalogen Compd. $66,2300-2305$.

Ibhazehiebo K., Iwasaki T., Shimokawa N. and Koibuchi N. 2011. 1,2,5,6,9,10- $\alpha$ hexabromocyclododecane (HBCD) impairs thyroid hormone-induced dendrite arborization of Purkinje cells and suppresses thyroid hormone receptor-mediated transcription. Cerebellum 10, 22-31.

IHPA. 2006. The legacy of lindane $\mathrm{HCH}$ isomer production: A global overview of residue management, formulation and disposal. International $\mathrm{HCH}$ and Pesticides Association. Available: www.ihpa.info.

IPCS. 1991. Lindane. Environmental Health Criteria 124. World Health Organization, Geneva. International Programme on Chemical Safety.

IPCS. 1992. Alpha- and beta-hexachlorocyclohexanes. Environmental Health Criteria 123. World Health Organization, Geneva. International Programme on Chemical Safety. Available: $h t t p: / / w w w . i n c h e m . o r g / d o c u m e n t s / e c h / e c h / e c h 123 . h t m$

Janak K., Covaci A., Voorspoels S. and Becher G. 2005. Hexabromocyclododecane in marine species from the Western Scheldt Estuary: Diastereoisomer- and enantiomer-specific accumulation. Environ. Sci. Technol. 39, 1987-1994.

Khan F.H., Ganesan P. and Kumar S. 2010. Y chromosome microdeletion and altered sperm quality in human males with high concentration of seminal hexachlorocyclohexane (HCH). Chemosphere 80, 972-977. 
Lau, M.H.Y., Leung K.M.Y., YuWong, S.W., Wang, H. and Yan, Z-G. (2012). Environmental policy, legislation and management of persistent organic pollutants (POPs) in China. Environ. Pollut., 165, 182-192.

Law K., Palace V.P., Halldorson T., Danell R., Wautier K., Evans B., Brinkworth L., Alaee M. and Tomy G.T. 2004. Dietary accumulation of hexabromocyclododecane isomers in juvenile rainbow trout (Oncorhynchus mykiss). The Third International Workshop on Brominated Flame Retardants, Toronto, 2004. Book of Abstracts, 2004, 433-436.

Law R.J., Alaee M., Allchin C.R., Boon J.P., Lebeuf M., Lepom P. and Stern G.A. 2003. Levels and trends of polybrominated diphenylethers and other brominated flame retardants in wildlife. Environ. Int. 29, 757-770.

Law R.J., Allchin C.R., de Boer J., Covaci A., Herzke D., Lepom P., Morris S., Tronczynsk J. and de Wit C.A. 2006. Levels and trends of brominated flame retardants in the European environment. Chemosphere 64, 187-208.

Law R.J., Kohler M., Heeb N.V., Gerecke A.C., Schmid P., Voorspoels S., Covaci A., Becher G., Janak K. and Thomson C. 2005. Hexabromocyclododecane challenges scientists and regulators. Environ. Sci. Technol.39, 281A-287A.

Legler J. 2008. New insights into the endocrine disrupting effects of brominated flame retardants. Chemosphere 73, 216-222.

Letcher R.J., Bustines J.O., Dietz R., Jenssen B.M., Jorgensen E.H., Sonne C., Verreault J., Vijayanm M. and Gabrielsen G.W. 2010. Exposure and effects assessment of persistent organohalogen contaminants in Arctic wildlife and fish. Sci.Total Environ. 408(15), 29953045 .

Li Y.F. 1999. Global technical hexachlorocyclohexane usage and its contamination consequences in the environment: from 1948-1997. Sci. Total Environ. 232, 121-128.

Li Y.F. and Bidleman T.F. 2003. Correlation between global emissions of $\alpha$ hexachlorocyclohexane and its concentration in the Arctic air. J. Environ. Inform. 1, 52-57.

Li Y.F. and Macdonald R.W. 2005. Sources and pathways of selected organochlorine pesticides to the Arctic and the effect of pathway divergence on $\mathrm{HCH}$ trends in biota: a review. Sci. Total Environ. 342, 87-106.

Lower N. and Moore A. 2007. The impact of a brominated flame retardant on smoltification and olfactory function in Atlantic salmon (Salmo salar L.) smolts. Mar. Freshw. Behav. Phy. 40(4), 267-284.

Mackay D., Shiu W.Y. and Ma K.C. 1997. Illustrated Handbook of Physical-chemical Properties and Environmental Fate for Organic Chemicals. CRC Press. 
Marvin C.H., Tomy G.T., Armitage J.M., Arnot J.A., McCarty L., Covaci A. and Palace V. 2011. Hexabromocyclododecane: Current understanding of chemistry, environmental fate and toxicology and implications for global management. Environ Sci Technol 45, 8613-8623.

Mathur V., Bhatnagar P., Sharma R.G., Acharya V. and Sexana R. 2002. Breast cancer incidence and exposure to pesticides among women originating from Jaipur. Environ. Int. 28(5), 331-336.

Ngabe B., Bidleman T.F. and Falconer R.L. 1993. Base hydrolysis of alpha- and gammahexachlorocyclohexanes. Environ. Sci. Technol. 27, 1930-1933.

Oliver B.G. and Niimi A.J. 1985. Bioconcentration factors for some halogenated organics for rainbow trout: Limitations in their use for prediction of environmental residues. Environ. Sci. Technol. 19(9), 842-849.

Palace V., Park B., Pleskach K., Gemmill B. and Tomy G. 2010. Altered thyroxine metabolism in rainbow trout (Oncorhynchus mykiss) exposed to hexabromocyclododecane (HBCD). Chemosphere 80, 165-169.

Pereira R.C., Monterroso C. and Macias F. 2010. Phytotoxicity of hexachlorocyclohexane: Effect on germination and early growth in different plant species. Chemosphere 79, 326333.

Reistad T., Fonnum F. and Mariussen E. 2006. Neurotoxicity of the pentabrominated diphenyl ether mixture, DE-71, and hexabromocyclododecane (HBCD) in rat cerebellar granule cells in vitro. Arch. Toxicol. 80, 785-796.

Roberts C.A. and Swigert J.P. 1997. Hexabromocyclododecane (HBCD): A 96-hour toxicity test with the freshwater alga (Selenastrum capricornutum). Final report, 439A-103. Wildlife International Ltd., Easton, Maryland, USA.

Schafer H., Hettler H., Fritsche G., Pitzen G., Roderer G. and Wenzel A. 1994. Biotests using unicellular algae and ciliates for predicting long-term effects of toxicants. Ecotoxicology and Environmental Safety 27, 64-81.

Schecter A., Szabo D.T., Miller J., Gent T.L., Malik-Bass N., Petersen M., Paepke O., Colacino J.A.. Hynan L.S., Harris T.R., Malla S. and Birnbaum L.S. 2012. Hexabromocyclododecane (HBCD) stereoisomers in U.S. Food from Dallas, Texas. Environ. Health Perspect.120(9), 1260-1264.

Schriks M., Zninavashe E., Furlow J.D. and Mark A.J. 2006. Disruption of thyroid hormonemediated Xenopus laevis tadpole tail tip regression by hexabromocyclododecane (HBCD) and 2, $2^{\prime}, 3,3^{\prime}, 4,4^{\prime}, 5,5^{\prime}, 6$-nonabrominated diphenyl ether (BDE206). Chemosphere 65, 1904-1908. 
Shen L., Wania F., Lei Y.D., Teixeira C., Muir D.C.G. and Bidleman T.F. 2005. Atmospheric distribution and long-range transport behaviour of organochlorine pesticides in North America. Environ. Sci. Technol. 39(2), 409-420.

Singh G., Kathpal T.S., Spencer W.F. and Dhankar J.S. 1991. Dissipation of some organochlorine insecticides in cropped and uncropped soil. Environ. Pollut. 70(3), 12191239.

Singh P.B. and Canario A.V.M. 2004. Reproductive endocrine disruption in the freshwater catfish, Heteropneustes fossilis, in response to the pesticide $\gamma$-hexachlorocyclohexane. Ecotoxicol. Environ. Saf. 58, 77-83.

Slooff W. and Mathijsen A.C.J.M. eds. 1988. Integrated criteria documents: hexachlorocyclohexanes. Bilthoven National Institute of Public Health and Environmental Protection (RIVM Report No. 758473011).

Solomon G.M. and Weiss P.M. 2002. Chemical contaminants in breast milk: Time trends and regional variability. Environ. Health Perspect. 110, A339-A347.

Stenzel, J. and Markley, B., 1997. Hexabromocyclododecane (HBCD): determination of the water solubility. Project Number: 439C-105. Wildlife International Ltd., Easton, MD

Swedish Chemicals Agency. 2008. Hexabromocyclododecane CAS-NO: 25637-99-45 EINECSNO: 247-148-4. Summary risk assessment report. Final report. 2008, Sweden.

Tiemann U. 2008. In vivo and in vitro effects of the organochlororine pesticide DDT, TCPM, methoxychlor and lindane on the female reproductive tract of mammals: A review. Reprod. Toxicol. 25, 316-326.

Tomy G.T., Budakowski W., Halldorson T., Whittle D.M., keir M.J., Marvin C., Macinnis G. and Alaee M. 2004. Biomagnification of $\alpha$ - and $\gamma$-hexabromocyclododecane isomers in Lake Ontario food web. Environ. Sci. Technol. 38, 2298-2303.

UNEP, 2001. Final act of the Conference of Plenipotentiaries on the Stockholm Convention on persistent organic pollutants. UNEP/POPS/CONF/4. Stockholm, 22-23 May 2001. United Nations Environment Programme.

UNEP, 2006. Report of the Persistent Organic Pollutants Review Committee on the work of its second meeting. Addendum. Risk profile on lindane. UNEP/POPS/POPRC.2/17/Add.4. 21 November 2006. United Nations Environment Programme.

UNEP, 2007a. Persistent Organic Pollutants Review Committee third meeting.Item 7 of the provisional agenda: Presentation on environmental transport and modelling. The OECD screening tool for overall persistence and long-range transport potential. UNEP/POPS/POPRC.3/INF/7. Geneva, 19-23 November 2007. United Nations Environment Programme. 
UNEP, 2007b. Stockholm Convention on Persistent Organic Pollutants: Persistent Organic Pollutants Review Committee third meeting. Additional information related to assessment of bioaccumulation data under Annex $D$ of the Convention. UNEP/POPS/POPRC.3/INF/8. Geneva, 19-23 November 2007. United Nations Environment Programme.

UNEP, 2009. Report of the Conference of the Parties of the Stockholm Convention on Persistent Organic Pollutants on the work of its fourth meeting. UNEP/POPS/COP.4/38. Geneva, 4-8 May 2009. United Nations Environment Programme.

UNEP, 2010a. Report of the Persistent Organic Pollutants Review Committee on the work of its sixth meeting. UNEP/POPS/POPRC.6/13. Geneva, 11-15 October 2010. United Nations Environment Programme.

UNEP, 2010b. Persistent Organic Pollutants Review Committee sixth meeting. Draft risk profile: hexabromocyclododecane. UNEP/POPS/POPRC.6/10. Geneva, 11-15 October 2010. United Nations Environment Programme.

UNEP, 2011. Persistent Organic Pollutants Review Committee seventh meeting. Draft risk management evaluation on hexabromocyclododecane. UNEP/POPS/POPRC.7/5. Geneva, 10 - 14 October 2011. United Nations Environment Programme.

UNEP, 2012. Global Chemicals Outlook

USEPA, 2006. Addendum to the 2002 Lindane Reregistration Eligibility Decision (RED). United States Environmental Protection Agency, July 2006. Available: http://www. epa.gov/oppsrrdl/REDs/lindane_red_addendum.pdf

USEPA, 2010. Hexabromocyclododecane (HBCD) Action Plan. United States Environmental Protection Agency, August 2010.

USEPA, (2007). High Production Volume (HPV) Challenge Program. http://www.epa.gov/hpv/index.htm

Veith G.D., DeFoe D.L. and Bergstedt B.V. 1979. Measuring and estimating the bioconcentration factors of chemicals in fish. J.Fish Res. Board Can. 36, 1040-1048.

Vijgen J., Abhilash P.C., Li Y.F., Lal R., Forter M., Torres J., Singh N., Yunus M., Tian C., Schaffer A. and Weber R. 2011. Hexachlorocylohexane as new Stockholm Convention POPs - a global perspective on the management of lindane and its waste isomers. Environ. Sc. Pollut. Res. 18, 152-162.

Walsh G.E., Yoder M.J., McLaughlin L.L. and Lores E.M. 1987. Responses of marine unicellular algae to brominated organic compounds in six growth media. Ecotoxicol. Environ. Saf. 14, 215-222. 
WHO, 1991. International Programme on Chemical Safety. Health and Safety Guide No.54. Lindane (gamma-HCH) health and safety guide. United Nations Environment Programme. International Labour Organization. World Health Organization. Geneva, 1991.

WHO Europe, 2003. Health risks of persistent organic pollutants from long-range transboundary air pollution. Joint WHO/Convention Task Force on the Health Aspects of Air Pollution. Chapter 3. Hexachlorocyclohexanes. Available: http://www.euro.who.int/Document/e78963.pdf

Willett K.L., Ulrich E.M. and Hites R.A. 1998. Differential toxicity and environmental fates of hexachlorocyclohexane isomers. Environ.Sci. Technol. 32, 2197-2207.

Wu J., Guan Y., Zhang Y., Luo X., Zhi H., Chen S. and Mai B. 2011. Several current-use, nonPBDE brominated flame retardants are highly bioaccumulative: Evidence from field determined bioaccumulation factors. Environ. Int. 37, 210-215.

WWFC, 1999. Lindane: A review of toxicity and environmental fate. World Wildlife Fund Canada, November 1999.

Zhao Z., Zhang L., Wu J. and Fan C. 2009. Distribution and bioaccumulation of organochlorine pesticides in surface sediments and benthic organisms from Taihu Lake, China. Chemosphere 77, 1191-1198.

Zou E. and Matsumura F. 2003. Long-term exposures to $\beta$-hexachlorocyclohexane $(\beta-\mathrm{HCH})$ promotes transformation and invasiveness of MCF-7 human breast cancer cells. Biochemical Pharmacology 66, 831-840. 